\title{
Sensory Attributes of Complex Tasting Divalent Salts Are Mediated by TRPM5 and TRPV1 Channels
}

\author{
Céline E. Riera, ${ }^{1}$ Horst Vogel, ${ }^{2}$ Sidney A. Simon, ${ }^{3}$ Sami Damak, ${ }^{1}$ and Johannes le Coutre ${ }^{1}$ \\ ${ }^{1}$ Nestlé Research Center, Vers-chez-les-Blanc, CH-1000 Lausanne, Switzerland, ${ }^{2}$ Ecole Polytechnique Fédérale de Lausanne, Institut des Sciences et \\ Ingénierie Chimiques, CH-1015 Lausanne, Switzerland, and ${ }^{3}$ Department of Neurobiology and Center for Neuroengineering, Duke University, Durham, \\ North Carolina 27710
}

Complex tasting divalent salts (CTDS) are present in our daily diet, contributing to multiple poorly understood taste sensations. CTDS evoking metallic, bitter, salty, and astringent sensations include the divalent salts of iron, zinc, copper, and magnesium. To identify pathways involved with the complex perception of the above salts, taste preference tests (two bottles, brief access) were performed in wild-type (WT) mice and in mice lacking (1) the T1R3 receptor, (2) TRPV1, the capsaicin receptor, or (3) the TRPM5 channel, the latter being necessary for the perception of sweet, bitter, and umami tasting stimuli. At low concentrations, $\mathrm{FeSO}_{4}$ and $\mathrm{ZnSO}_{4}$ were perceived as pleasant stimuli by WT mice, and this effect was fully reversed in TRPM5 knock-out mice. In contrast, $\mathrm{MgSO}_{4}$ and CuSO $\mathrm{Cere}_{4}$ aversive to WT mice, but for $\mathrm{MgSO}_{4}$ the aversion was abolished in TRPM5 knock-out animals, and for $\mathrm{CuSO}_{4}$, aversion decreased in both TRPV1- and TRPM5-deficient animals. Behavioral tests revealed that the T1R3 subunit of the sweet and umami receptors is implicated in the hedonically positive perception of $\mathrm{FeSO}_{4}$ and $\mathrm{ZnSO}_{4}$. For high concentrations of CTDS, the omission of TRPV1 reduced aversion. Imaging studies on heterologously expressed TRPM5 and TRPV1 channels are consistent with the behavioral experiments. Together, these results rationalize the complexity of metallic taste by showing that at low concentrations, compounds such as $\mathrm{FeSO}_{4}$ and $\mathrm{ZnSO}_{4}$ stimulate the gustatory system through the hedonically positive T1R3-TRPM5 pathway, and at higher concentrations, their aversion is mediated, in part, by the activation of TRPV1.

Key words: metallic taste; divalent salts; taste preference; TRP channels; T1R3; calcium/voltage imaging

\section{Introduction}

Although divalent salts such as zinc, iron, copper, and magnesium are essential bioavailable elements (O'Dell and Sunde, 1997), the molecular mechanisms of their sensory signal transduction remains to be elucidated. All these salts exhibit a complex taste profile. Ferrous sulfate $\left(\mathrm{FeSO}_{4}\right)$ is the prototypical metallictasting compound, described as rusty iron, "penny like," fishy, and rancid (Civille and Lyon, 1996; Lawless et al., 2004; Lim and Lawless, 2005a,b; Yang and Lawless, 2005), but is also perceived as astringent/drying, with some sour and bitter attributes (Lawless et al., 2004; Lim and Lawless, 2005a,b). Salts containing zinc are characterized as astringent with some other qualities such as umami, burning, bitter, sour, salty, and metallic (Keast et al., 2003; Yang and Lawless, 2005; Lim and Lawless, 2005a). Coppercontaining salts evoke strong bitter, astringent, and metallic taste sensations (Lawless et al., 2004, 2005). Magnesium-containing salts are primarily bitter tasting with additional sensations described as salty, metallic, astringent, sour, and sweet (Schiffman

\footnotetext{
Received Sept. 30, 2008; revised Dec. 20, 2008; accepted Jan. 13, 2009.

We thank Muriel Briand, Cristina Cartoni, and Carole Bezençon for technical assistance and Robert Virgili for assistance with software programming.

Correspondence should be addressed to either of the following: Johannes le Coutre or Céline E. Riera (for technical questions), Nestlé Research Center, P.0. Box 44, CH-1000 Lausanne 26, Switzerland, E-mails: johannes. le-coutre@rdls.nestle.com or celine.riera@epfl.ch.

DOI:10.1523/JNEUROSCI.4694-08.2009

Copyright $\odot 2009$ Society for Neuroscience $\quad 0270-6474 / 09 / 292654-09 \$ 15.00 / 0$
}

and Erickson, 1971; Lawless et al., 2004; Lim and Lawless, 2005b; Yang and Lawless, 2005). Therefore, despite a common metallic denominator, the sensory profiles of the above named divalent salts are complex, vary with the concentration, and involve not only taste but also tactile properties such as astringency and, in the case of $\mathrm{FeSO}_{4}$, retronasal smell (Lim and Lawless, 2005a; Yang and Lawless, 2005). Whether and how these salts stimulate taste receptors remains unclear, although a recent study has shown that the T1R3 receptor is involved in the detection of $\mathrm{Ca}^{2+}$ and $\mathrm{Mg}^{2+}$ (Tordoff et al., 2008). In that study, it was found that hedonic values for $\mathrm{Ca}^{2+}$ and $\mathrm{Mg}^{2+}$ were related to specific T1R3 haplotypes and that T1R3 knock-out (KO) mice in a C57BL/6 background preferred these two cations whereas they were avoided by their wild-type (WT) littermates.

Previously, we found that complex-tasting divalent salts (CTDS) activate heterologously expressed human TRPV1 (hTRPV1) channels, pointing to the involvement of this channel in the aversive component of their taste (Riera et al., 2007). TRPV1 is a member of the transient receptor potential (TRP) channel family known to be activated by heat, acid, multivalent cations, and capsaicin, the primary pungent ingredient in chili pepper (Caterina et al., 1997; Tominaga et al., 1998; Ahern et al., 2006).

The perception of many food-borne compounds is mediated by both the gustatory and somatosensory systems (Simon et al., 2006). The gustatory system detects chemical stimuli dissolved in 
saliva, whereas the somatosensory system detects thermal, mechanical, and chemical stimuli, many of which, like capsaicin, are nonpolar irritants that can diffuse into the lingual epithelium where they can activate receptors on nerve terminals. In both systems, TRP channels are involved in the transduction pathways. For taste transduction, TRPM5 is a critical element in the downstream signaling of sweet, bitter, and umami tastes, and TRPM5-deficient mice exhibit complete or markedly diminished responses to the tastants associated with these sensations (Zhang et al., 2003; Damak et al., 2006). With regard to chemesthesis, polymodal nociceptors in the oral cavity contain several thermally sensitive TRP channels, including TRPV1 (Bandell et al., 2007).

To obtain a better understanding of the pathways involved in the multiplicity of taste sensations elicited by CTDS, we performed behavioral tests using mice lacking T1R3 receptors, TRPM5, or TRPV1 channels. Our findings indicate that low concentrations of $\mathrm{FeSO}_{4}$ and $\mathrm{ZnSO}_{4}$ are preferred and high concentrations are aversive. We also found that T1R3, TRPV1, and TRPM5 are involved to various extent in the transduction of the taste of CTDS.

\section{Materials and Methods}

Chemicals. Capsaicin, $\mathrm{MgSO}_{4}, \mathrm{CuSO}_{4}, \mathrm{ZnSO}_{4} \cdot 1 \mathrm{H}_{2} \mathrm{O}$, and $\mathrm{FeSO}_{4} \cdot 1 \mathrm{H}_{2} \mathrm{O}$ were obtained at chemical-grade purity from Sigma-Aldrich. Sulfate anions were chosen as a common counter-ion to be coupled to divalent cations of iron, zinc, copper, and magnesium because they have little or no impact on the sensory properties of these metallic salts (Lim and Lawless, 2005b; Yang and Lawless, 2005). In addition, they form fewer complexes than chloride salts (Martell and Hancock, 1996). The range of concentrations and $\mathrm{pH}$ values of the compounds used is summarized in supplemental Table S1 (available at www.jneurosci.org as supplemental material).

Expression of hTRPV1 and TRPM5 in HEK293 cells. Human TRPM5 cDNA clone (Origene) in a PCMV-XL6 vector and hTRPV1 cDNA clone (RZPD) in pcDNA5/FRT (Invitrogen) were transiently transfected in HEK293 cells. Cells were grown as monolayers in DMEM (Sigma) supplemented with nonessential amino acids, $10 \%$ fetal bovine serum, and 2 mM L-glutamine and maintained at $37^{\circ} \mathrm{C}$ under $95 \% / 5 \% \mathrm{O}_{2} / \mathrm{CO}_{2}$. Transfected cells were plated into 96-well plates (Corning Life Sciences) previously coated with poly-D-lysine at a density of 100,000 cells/well and were grown for $1 \mathrm{~d}$.

Site-directed mutagenesis of TRPV1. Point mutations Y511A, E600Q, and E649A in hTRPV1 homologous to rat Y511A, E600Q, and E648A were generated after verifying that these regions were conserved across species. Point mutants were obtained using the Quick Change SiteDirected Mutagenesis kit (Stratagene) on the hTRPV1 clone. After sequence verification, mutants were transiently expressed in HEK293 cells, and the respective sensitivity of Y511A, E600Q, and E649A to capsaicin and acidic $\mathrm{pH}$ (Jordt et al., 2000; Jordt and Julius, 2002) was verified by voltage imaging.

Measurement of membrane potential using a fluorescence plate reader. Voltage imaging quantifies membrane depolarization because of ionic entry induced by stimulation of membrane ion channels and changes in fluorescence of a membrane potential sensitive dye. This method was used over calcium imaging (monitoring increase in intracellular calcium via excitation of a fluorescent dye) because TRPM5 is a nonselective cation channel that carries $\mathrm{Na}^{+}, \mathrm{K}^{+}$, and $\mathrm{Cs}^{+}$ions equally well, but not $\mathrm{Ca}^{2+}$ ions (Prawitt et al., 2003). For membrane potential assays, cells at the same density were loaded with a voltage-sensitive dye according to the manufacturer's protocol (Red dye; Molecular Devices). The 96-well plates were then placed into the plate reader (FLEXstation; Molecular Devices) to measure changes in fluorescence intensty (FI) of the voltage sensitive dye at F530/565 $\left(\lambda_{\text {ex } 1}=530 \mathrm{~nm} ; \lambda_{\text {em }}=565 \mathrm{~nm}\right)$.

CTDS were dissolved in HBSS supplemented with $2 \mathrm{mM} \mathrm{CaCl}_{2}$ and 20 mM HEPES buffered at $\mathrm{pH}$ 7.4. In TRPM5 assays, calcium was omitted from the HBSS. For all experiments, voltage changes were measured as
Table 1. Summary of statistical analysis of behavioral data

\begin{tabular}{lllll}
\hline & $p$ & & & \\
\cline { 2 - 5 } & $\mathrm{FeSO}_{4}$ & $\mathrm{ZnSO}_{4}$ & CuSO $_{4}$ & $\mathrm{MgSO}_{4}$ \\
\hline TBP & & & & \\
TRPM5 K0 vs WT & 0.0001 & 0.0001 & $0.327^{0.1-50 \mathrm{~mm}}$ & 0.006 \\
$\quad$ TRPV1 K0 vs WT & $0.009^{50-200 \mathrm{~mm}}$ & $0.229^{30-100 \mathrm{~mm}}$ & $0.055^{0.1-50 \mathrm{~mm}}$ & 0.94 \\
BA & & 0.054 & 0.044 & 0.022 \\
TRPM5 K0 vs WT & 0.001 & 0.25 & 0.759 & 0.596 \\
TRPV1 K0 vs WT & 0.499 & 0.012 & ND & ND \\
$\begin{array}{l}\text { TBP } \\
\text { T1R3 K0 vs WT }\end{array}$ & 0.0001 & & & \\
T1R3 K0 vs & & 0.08 & ND & ND \\
TRPM5K0 & 0.085 & & & \\
\hline
\end{tabular}

The GLM for repeated-measurement analysis was used to compare the responses of TRPM5 K0, TRPV1 K0, T1R3 KO and WT with tastant concentrations as dependent variables and genotype as a fixed factor. For each compound, the responses for all concentrations were analyzed together. The Tukey's test was used to determine which of the means differed when a difference was found. For comparisons of TRPV1 KO versus WT mice, only the results of the aversive concentrations are shown. $p$ values are given for the comparison between two genotypes. ND, Not done.

increases in FI, before and after the addition of the various compounds. The FIs were taken to be their maximum value and were obtained by subtracting the corresponding fluorescence background (value before stimulation). Data were expressed as mean \pm SEM.

Animals. TRPV1 KO mice (Caterina et al., 2000) were obtained from The Jackson Laboratory. TRPM5 KO mice were purchased from Deltagen. The mutation in TRPM5 consists of a $174 \mathrm{nt}$ deletion in exon 14 corresponding to the second transmembrane domain and some flanking sequence, and also the introduction of a Neo-LacZ cassette at the site of the deletion. The founder mice were generated in 129/OlaHsd and were backcrossed for six generations with C57BL/6J mice to generate TRPM5 $\mathrm{KO}$ mice in a 97\% C57BL/6J background. The T1R3 KO mice were produced by removing the entire coding sequence of T1R3, which was replaced with a Neo and enhanced green fluorescent protein cassette. The T1R3 KO mice are in a 100\% C57BL/6J background.

Two-bottle preference tests. KO mice and C57BL/6 WT mice (age and gender matched, males and females) were tested with different compounds. Group 1 (10 TRPV1 KO, 10 TRPM5 KO, 10 WT littermates) was tested with increasing concentrations of $\mathrm{FeSO}_{4}, \mathrm{ZnSO}_{4}, \mathrm{CuSO}_{4}$, and $\mathrm{MgSO}_{4}$ (Table 1). Group 2 (10 T1R3 KO, 10 WT littermates) was tested with increasing concentrations of $\mathrm{FeSO}_{4}$ and $\mathrm{ZnSO}_{4}$. Mice were caged individually and given access for $48 \mathrm{~h}$ to two $25 \mathrm{ml}$ bottles, one containing distilled water and the other containing a tastant solution. After $24 \mathrm{~h}$, bottle positions were switched to control for positional effects (Wong et al., 1996; Caterina et al., 2000). The volumes of liquid consumed were measured by weighing the bottles before and after $48 \mathrm{~h}$. The preference ratio $(\mathrm{PR})$ defined as the ratio of tastant volume $\left(\mathrm{V}_{1}\right)$ to total liquid consumed $\left(\mathrm{V}_{\mathrm{t}}\right)$ was calculated. A ratio of 0.5 indicates indifference, a ratio above 0.5 indicates preference, and a ratio below 0.5 indicates avoidance. The presentation of the tastants was in ascending concentration. Between tastant trials, the mice were given distilled water for $7 \mathrm{~d}$ in two bottles.

Brief-access taste tests. Three groups of 15 naive mice each were used: TRPV1 KO, TRPM5 KO, and WT C57BL/6 age- and gender-matched controls. Brief-access taste (BA) tests were conducted using a gustometer (Davis MS160-Mouse gustometer; Dilog Instruments). Mice that did not get accustomed to the gustometer were excluded from the study. Briefaccess tests were performed in naive animals presented with four to five concentrations that were selected based on the results of the two-bottle preference (TBP) test. The training and testing procedures were conducted following previously described protocols (Glendinning et al., 2002; Damak et al., 2006). Over a 30 min testing period, the mice were presented alternatively with two bottles, one containing the tastant and the other containing distilled water. When the mouse starts licking, it begins a $5 \mathrm{~s}$ trial after which the shutter is closed and the other bottle is presented. The number of licks per trial is recorded. Mice were tested with four concentrations of $\mathrm{FeSO}_{4}, \mathrm{ZnSO}_{4}, \mathrm{CuSO}_{4}$, and $\mathrm{MgSO}_{4}$. The lick ratio (LR) was calculated to be the mean number of licks per trial for the tastant $\left(\mathrm{L}_{1}\right)$ divided by the mean number of licks per trial for tastant plus the mean number of licks per trial for water $\left(\mathrm{L}_{\mathrm{t}}\right)$. 
Statistical analysis. PRs for the TBP and the $\mathrm{BA}$ tests and the volumes consumed in the TBP test were analyzed using the general linear model (GLM) repeated measures of the statistics package SPSS with tastant concentration as the within-subject factor and genotype as the between-subject factor. Significance of the between-subject factor indicates difference in the responses between genotypes, whereas significance of the within-subject factor for a given genotype indicates either preference and/or avoidance of certain concentrations of the tastant. A $p$ value $<0.05$ was considered significant. When a significant difference was found between genotypes, the Tukey's test was used to determine which genotypes differ. For biphasic tastant responses, the preferred and aversive concentrations were grouped and analyzed separately using the GLM as described above. For compounds with borderline values $(0.05<p<$ 1 ), we analyzed each concentration separately with the GLM and used the Bonferroni's correction to correct for multiple tests on related data sets.

\section{Results}

The cellular responses to CTDS are mediated by TRPM5- and TRPV1-dependent pathways

To determine the contribution of TRPM5 and TRPV1 to the taste preferences of CTDS, we performed behavioral tests with WT, TRPM5, and TRPV1 KO mice. The CTDS tested include several concentrations of $\mathrm{FeSO}_{4}, \mathrm{ZnSO}_{4}$, $\mathrm{CuSO}_{4}$, and $\mathrm{MgSO}_{4}$. These concentrations covered a broad range and were chosen based on concentrations used in human psychophysical studies (Lim and Lawless, 2005a,b; Yang and Lawless, 2005).

\section{TBP tests}

$\mathrm{FeSO}_{4}$ and $\mathrm{ZnSO}_{4}$ WT mice exhibited biphasic response profiles to $\mathrm{FeSO}_{4}$ and $\mathrm{ZnSO}_{4}$ (i.e., these salts were preferred over water at low concentrations and were avoided at higher concentrations) (Fig. 1A,B). Biphasic effects to a tastant can occur if different taste or sensory pathways are activated as a function of tastant concentration (Kawamura et al., 1968; Simon et al., 2006). Biphasic responses have been described for many different tastants (Pfaffmann, 1980; Riera et al., 2008). For the CTDS, it follows that the biphasic response involves hedonically positive and negative pathways. The WT mice had increasing PRs to $\sim 0.8$ for $30 \mathrm{mM} \mathrm{FeSO}_{4}$ and 10 $\mathrm{mm} \mathrm{ZnSO}_{4}$. Over a $48 \mathrm{~h}$ period, this preference corresponded to an intake of $7 \mathrm{ml}$ of $\mathrm{FeSO}_{4}$ and $10 \mathrm{ml}_{\text {of }} \mathrm{ZnSO}_{4}$ (supplemental Fig. $\mathrm{S} 1$, available at www.jneurosci.org as supplemental material). These two salts provoked aversive responses at concentrations higher than $50 \mathrm{mM}$, a concentration at which the $\mathrm{PR}$ was $\sim 0.5$. At the highest concentrations tested, $250 \mathrm{mM} \mathrm{FeSO}_{4}$ (PR, $0.15 \pm$ $0.05)$ and $100 \mathrm{~mm} \mathrm{ZnSO}_{4}(\mathrm{PR}, 0.2 \pm 0.1)$ were strongly aversive. Over the $48 \mathrm{~h}$ testing period, the highest concentration intakes corresponded to a volume of $1.1 \mathrm{ml}^{\text {of }} \mathrm{FeSO}_{4}$ and $1.4 \mathrm{ml}$ of $\mathrm{ZnSO}_{4}$ (supplemental Fig. S1, available at www.jneurosci.org as supplemental material).

For the TRPM5 KOs, at all concentrations in which these two salts could be distinguished from water, the PR was $<0.5$ and therefore hedonically negative and globally significantly different
B

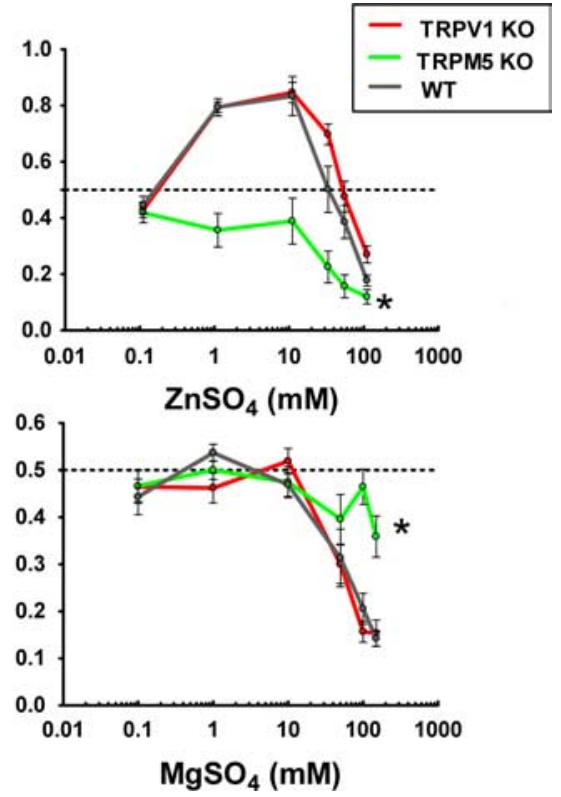

Figure 1. Mean PRs from $48 \mathrm{~h}$ two-bottle tests (tastant vs water) comparing the responses to CTDS from WT with TRPV1 K0 and TRPM5 $\mathrm{KO}$ mice. The mice have access to two bottles, one containing water and the other containing a tastant solution. PRs of , of the TRPM5 K0 mice is significantly different from those of WT animals; + concentrations are significantly different from those of WT animals. The dashed line indicates indifference (PR, 0.5).

from the PR of WT mice $(p<0.0001)$. Even at the higher concentrations $(>50 \mathrm{mM})$ that were aversive to WT mice, these tastants were even more aversive to the TRPM5 KOs. For these high concentrations, over the $48 \mathrm{~h}$ trial the TRPM5 KO mice consumed $<1 \mathrm{ml}$ of the tastant. These data indicate the presence of at least two pathways contributing to the transduction of the taste of $\mathrm{FeSO}_{4}$ and $\mathrm{ZnSO}_{4}$, one of which is TRPM5 dependent.

We next inquired whether in TRPM5 KOs the residual aversion to $\mathrm{FeSO}_{4}$ and $\mathrm{ZnSO}_{4}$ could be, at least in part, caused by the activation of TRPV1 channels. To answer this question, we compared the PRs from WT and TRPV1 KO mice. For the preferred (hedonically positive) concentrations of both salts, the $\mathrm{KO}$ mice behaved similarly to the WT mice, whereas at high concentrations of $\mathrm{FeSO}_{4}(>30 \mathrm{~mm})$ the TRPV1 $\mathrm{KO}$ mice showed a reduced aversion compared with WT mice $(p<0.01)$ (Fig. $1 A)$. Such difference between the two genotypes was absent for $\mathrm{ZnSO}_{4}$. At $250 \mathrm{mM} \mathrm{FeSO}_{4}$, the TRPV1 KOs ingested, on average, $1.4 \mathrm{ml}$ versus $1.1 \mathrm{ml}$ for the $\mathrm{WT}$, whereas for $\mathrm{ZnSO}_{4}$, the TRPV1 KO ingested, on average, $1.9 \mathrm{ml}$ versus $1.4 \mathrm{ml}$ for the WT. There was no significant difference $(p>0.05)$ between TRPV1 KO and WT mice for the aversive concentrations of $\mathrm{ZnSO}_{4}$.

$\mathrm{CuSO}_{4}$ and $\mathrm{MgSO}_{4}$

Unlike the biphasic responses to $\mathrm{FeSO}_{4}$ and $\mathrm{ZnSO}_{4}$ the responses of WT mice to $\mathrm{CuSO}_{4}$ and $\mathrm{MgSO}_{4}$ were found to be monotonically aversive (Figs. 1C,D). We first report the responses to $\mathrm{CuSO}_{4}$. For concentrations $>0.01 \mathrm{~mm} \mathrm{CuSO}_{4}$, all three mouse strains exhibited an aversive response. Whereas the statistical significance of the difference between TRPV1 KO and WT mice is borderline ( $p=0.05)$, the PRs for the TRPM5 KO mice were indistinguishable from the WTs $(p>0.05)$. However, only for 10 $\mathrm{mM} \mathrm{CuSO}_{4}$ there was a significant $(p<0.0001)$ decrease in aversion between TRPM5 KO or TRPV1 KO mice versus WT ani- 
A

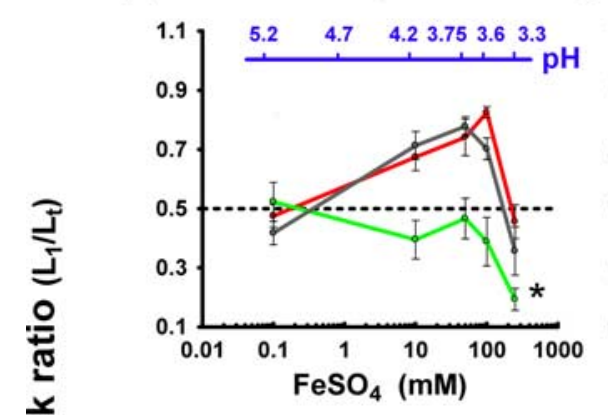

B

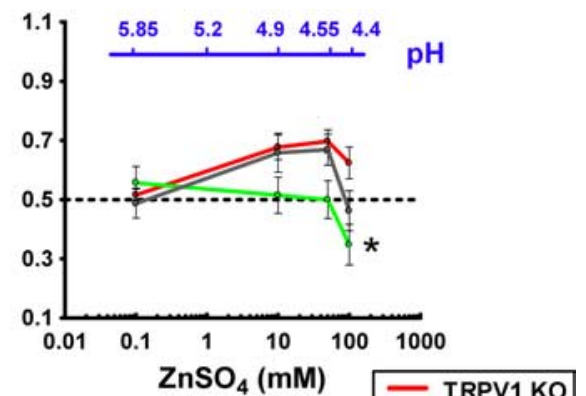

C

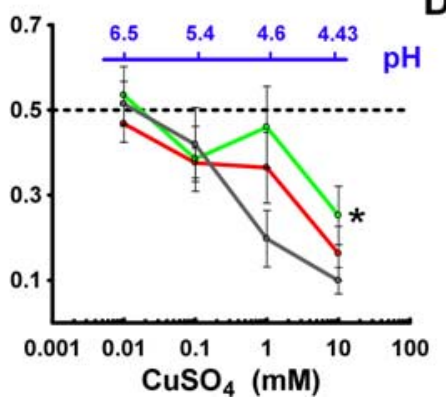

$\mathrm{CuSO}_{4}(\mathrm{mM})$

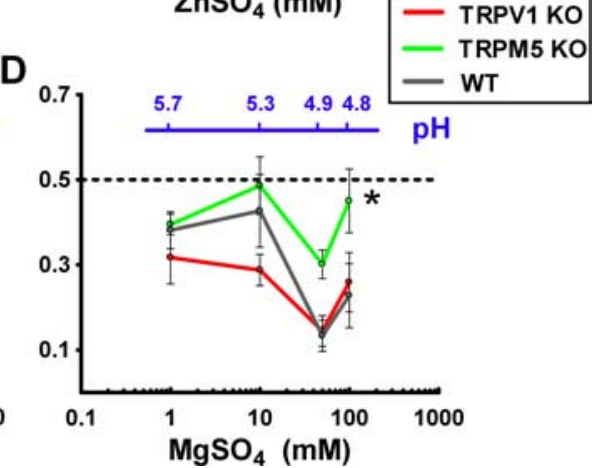

Figure 2. Brief-access LRs (tastant vs water) comparing the responses to CTDS from WT with TRPV1 KO and TRPM5 KO mice. The mice had $5 \mathrm{~s}$ access to alternatively presented water or tastant. LRs of TRPV1 KO, TRPM5 KO, and WT mice for $\mathrm{FeSO}_{4}(\boldsymbol{A}), \mathrm{ZnSO}_{4}$ $(\boldsymbol{B}), \mathrm{CuSO}_{4}(\boldsymbol{C})$, and $\mathrm{MgSO}_{4}(\boldsymbol{D})$ are shown. $n=10$ in each group. Error bars indicate SEM. ${ }^{*}$ The global response of the TRPM5 KO mice are significantly different from those of WT animals.

mals. At the highest concentration tested, all mice showed a similar pronounced aversion with a $\mathrm{PR}<0.1$ and ingested only small volumes $(<1 \mathrm{ml}$ ), as seen in supplemental Figure S2 (available at www.jneurosci.org as supplemental material). In summary, the elimination of TRPM5 or TRPV1 did not substantially alter the negative hedonic responses to $\mathrm{CuSO}_{4}$. Because $\mathrm{CuSO}_{4}$ is an emetic (Makale and King, 1992), the remaining aversion in the $\mathrm{KO}$ mice could be caused by postingestive responses.

For $>50 \mathrm{mM} \mathrm{MgSO}_{4}$, the responses of TRPM5 KO mice revealed a markedly decreased aversion $(p<0.01)$. In contrast, the responses of the WT and TRPV1 KOs were not statistically different over all concentrations with intakes $<2 \mathrm{ml}$ for $>50 \mathrm{mM}$ $\mathrm{MgSO}_{4}$. In summary, the hedonically negative component of the taste of $\mathrm{MgSO}_{4}$ is mediated by a pathway containing TRPM5 but not TRPV1.

\section{Brief-access tests}

Because the behavioral responses in the TBP tests may be partly caused by postingestive cues and some of the compounds tested have emetic properties such as $\mathrm{FeSO}_{4}, \mathrm{ZnSO}_{4}$, and $\mathrm{CuSO}_{4}$ (Wang and Borison, 1951; Reissman et al., 1955; Makale and King, 1992; Barceloux, 1999), we performed BA tests to reduce the postingestive component of the TBP test. To assess the sensory contribution of increased acidity produced by the CTDS, we plotted the $\mathrm{pH}$ values of the solutions in Figure 2 (see also supplemental Table 1, available at www.jneurosci.org as supplemental material).

$\mathrm{FeSO}_{4}$ and $\mathrm{ZnSO}_{4}$

As seen in Figure 2, $A$ and $B$, biphasic responses to $\mathrm{FeSO}_{4}$ and $\mathrm{ZnSO}_{4}$ were also observed in the BA tests.

$\mathrm{FeSO}_{4}$ was maximally preferred by WT mice at concentrations up to $100 \mathrm{~mm}$ and avoided at $250 \mathrm{~mm}$. Knocking out TRPM5 completely eliminated the preference for $\mathrm{FeSO}_{4}$ and increased its aversion at all concentrations $(p<0.001$, compared with WT mice). The responses of $\mathrm{WT}$ and TRPV1 $\mathrm{KO}$ mice to $\mathrm{FeSO}_{4}$ were statistically indistinguishable $(p=0.78)$.

WT mice preferred $\mathrm{ZnSO}_{4}$ at concentrations up to $50 \mathrm{~mm}$ and were indifferent to this compound at $100 \mathrm{~mm}$. TRPM5 KO mice were indifferent to all concentrations of $\mathrm{ZnSO}_{4}$ up to $50 \mathrm{~mm}$ and avoided it at $100 \mathrm{~mm}$ ( $p<0.05$, compared with WT mice). The responses of the TRPV1 KO and WT mice were statistically indistinguishable.

$\mathrm{CuSO}_{4}$ and $\mathrm{MgSO}_{4}$

Consistent with the TBP test, the responses of WT mice to $\mathrm{CuSO}_{4}$ and $\mathrm{MgSO}_{4}$ in the BA test were found to be aversive for all concentrations $>0.1 \mathrm{~mm}$ for $\mathrm{CuSO}_{4}$ and $1 \mathrm{~mm}$ for $\mathrm{MgSO}_{4}$ (Fig. 2C,D). Knocking out TRPM5 reduced the aversion for both salts without completely abolishing it $(p<0.05$, WT compared with TRPM5 $\mathrm{KO})$. The responses of the TRPV1 KO and WT mice were indistinguishable.

\section{Comparison of TBP and BA tests \\ $\mathrm{FeSO}_{4}$ and $\mathrm{ZnSO}_{4}$}

The results of the two behavioral tests are in general agreement. That is, both the TBP and the BA tests revealed a biphasic response pattern of WT mice to $\mathrm{FeSO}_{4}$ and

$\mathrm{ZnSO}_{4}$ (Figs. $1 A, B, 2 A, B$ ). The PR maxima occurred at a lower concentration in the TBP test than in the BA test $(10 \mathrm{vs} 50 \mathrm{~mm}$, respectively). Furthermore, the TRPM5 KO mice avoid lower concentrations of these salts in the TBP test but are indifferent to them in the BA test. The most likely explanation for these observations is the added contribution to aversion of the postingestive effect, which could be a digestive malaise that discourages the mice from drinking the CTDS solutions.

For TRPV1 KO mice, the response to $\mathrm{FeSO}_{4}$ was significantly different from that of WT mice when measured by the TBP test, but only a trend was observed in the BA test. This discrepancy likely arises from a difference in the experimental method used; in our experience, we found the TBP test more robust in revealing small differences between groups because the animal-to-animal variation is smaller in the TBP than the BA method (S. Damak, unpublished observation).

$\mathrm{CuSO}_{4}$ and $\mathrm{MgSO}_{4}$

For $\mathrm{CuSO}_{4}$ and $\mathrm{MgSO}_{4}$, the general shape of the concentrationresponse curves was similar for the TBP test and the BA test. For concentrations $>0.1 \mathrm{mM} \mathrm{CuSO}_{4}$, the responses of the TRPM5 $\mathrm{KO}$ mice were overall significantly different from the WT in the BA test $(p<0.05)$, whereas in the TBP test only $10 \mathrm{~mm}$ gave a significant difference. This difference could be explained by a large postingestive component in the TBP test. The responses of TRPV1 KO mice were statistically different from the WT in the TBP test $(p=0.05)$ but not in the BA test $(p>0.05)$, although there was a trend for a difference in the BA test.

For $\mathrm{MgSO}_{4}$, both tests are in good agreement, indicating that this salt's aversive response can be fully accounted for by the TRPM5 component. No shift was observed in the PR-concentration profile between the two tests, suggesting that suppression of the postingestive component did not alter the preference. 

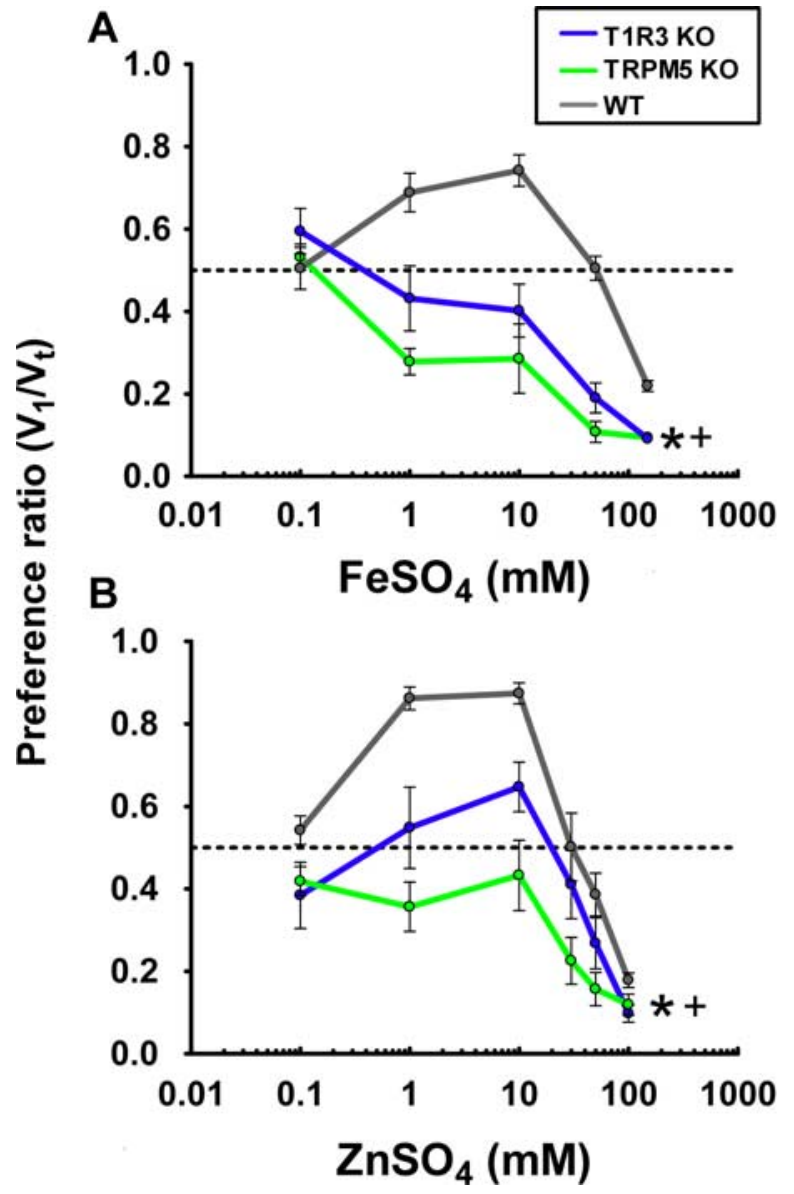

Figure 3. Mean PRs from $48 \mathrm{~h} \mathrm{TBP}$ tests of responses to $\mathrm{FeSO}_{4}$ and $\mathrm{ZnSO}_{4}$ on T1R3 KO, TRPM5 $\mathrm{KO}$, and WT mice. The PR was measured and compared between WT and $\mathrm{T} 1 \mathrm{R} 3 \mathrm{KO}$ mice for FeSO $(\boldsymbol{A})$ and $\mathrm{ZnSO}_{4}(\boldsymbol{B})$. For comparison, the PR of TRPM5 $\mathrm{KO}$ mice is also plotted. T1R3 $\mathrm{KO}$ mice are essentially indifferent to concentrations of $\mathrm{FeSO}_{4}$ and $\mathrm{ZnSO}_{4}$ that are preferred by WT mice. $n=$ 10 in each group. Error bars indicate SEM. The global responses of the TRPM5 KO $\left.{ }^{*}\right)$ and the T1R3 $\left.\mathrm{KO}^{+}\right)$are significantly different from those of WT mice.

T1R3 is involved in the transduction of the taste responses to $\mathrm{FeSO}_{4}$ and $\mathrm{ZnSO}_{4}$

A subpopulation of TRPM5-containing cells expresses T1R3, which is implicated in the transduction of the hedonically positive responses to sweet and umami compounds (Damak et al., 2003; Zhao et al., 2003). Therefore, we investigated whether T1R3 is involved in the transduction of the preferred component of the tastes of $\mathrm{FeSO}_{4}$ and $\mathrm{ZnSO}_{4}$.

T1R3 KO mice were essentially indifferent to concentrations of $\mathrm{FeSO}_{4}$ and $\mathrm{ZnSO}_{4}$ that are preferred by WT mice but showed a greater aversion to higher concentrations than WT mice (Fig. 3) $\left(\mathrm{FeSO}_{4}, p<0.0001 ; \mathrm{ZnSO}_{4}, p<0.05\right)$. Compared with the TRPM5 KO mice, the T1R3 KOs showed a trend for less aversion to $\mathrm{FeSO}_{4}$ and $\mathrm{ZnSO}_{4}$ ( $p=0.085$ and $p=0.08$, respectively). Therefore, a T1R3-containing pathway accounts for most of the preference imparted by these salts, but a T1R3-independent pathway containing TRPM5 might also contribute to the preference.

\section{Effects of CTDS on heterologously expressed hTRPM5 channels}

Previously, we showed that heterologously expressed hTRPV 1 in $\mathrm{HEK} 293$ cells could be activated by $\mathrm{FeSO}_{4}, \mathrm{ZnSO}_{4}, \mathrm{CuSO}_{4}$, and $\mathrm{MgSO}_{4}$ (Riera et al., 2007). To determine whether CTDS could also activate TRPM5 channels, we expressed hTRPM5 in HEK293 cells, and we measured evoked changes in voltage in response to CTDS. TRPV1-transfected HEK293 cells were used as positive controls, and nontransfected HEK293 cells were used as negative controls. As indicated by increases in fluorescence, after stimulation by CTDS, hTRPV1-expressing cells evoked large changes in voltage. Depolarizations were also observed in calcium-free HBSS, consistent with results showing that HEK293 cells expressing TRPV 1 can be depolarized by the influx of cations through the TRPV1 channel (Ahern et al., 2005; Riera et al., 2007).

The response of nontransfected HEK293 cells to CTDS was weak and varied depending on the particular salt tested. At 10 $\mathrm{mM}, \mathrm{FeSO}_{4}$ evoked a biphasic response (a transient depolarization followed by a small hyperpolarization), whereas $\mathrm{ZnSO}_{4}$ evoked a transient hyperpolarization followed by a long depolarization, $\mathrm{CuSO}_{4}$ evoked a slow depolarizing response, and $\mathrm{MgSO}_{4}$ evoked a small hyperpolarization. The origin of these responses is unknown but could in part reflect responses to changes in volume or complexes of the divalent cations with chloride that could permeate into the cell (Gutknecht, 1981).

In TRPM5-transfected cells, the responses to $\mathrm{ZnSO}_{4}$ and $\mathrm{CuSO}_{4}$ were virtually identical to the responses of nontransfected cells (Fig. $4 \mathrm{~B}, \mathrm{C}$ ). It is seen that $\mathrm{FeSO}_{4}$ and $\mathrm{MgSO}_{4}$ evoked marginally larger hyperpolarizing responses than found in nontransfected cells (Fig. 4A,D). No difference in response was observed when $2 \mathrm{~mm}$ extracellular calcium was added to the medium for both transfected and nontransfected cells (data not shown). Thapsigargin $(5 \mu \mathrm{M})$ induced a large and transient increase in fluorescence, which is consistent with an endogenous calcium release activating TRPM5, leading to depolarization of the cell (supplemental Fig. S4, available at www.jneurosci.org as supplemental material). In summary, the results from these experiments indicate that these salts, should they diffuse or be transported to the basolateral side of taste cells where TRPM5 is located (Kaske et al., 2007), are unlikely to directly activate TRPM5. In this regard, direct activation of the TRPM5 channel is unlikely to account for the behavioral changes seen with these compounds.

\section{Different CTDS stimulate different binding sites in TRPV1}

Because TRPV1 governs some of the behavioral responses to CTDS, we explored how this channel may be activated by these salts. TRPV1 possesses multiple ligand binding sites; among them are an intracellular capsaicin-binding pocket (Jordt and Julius, 2002) and an extracellular proton-sensitive region (Jordt et al., 2000). Point mutations of critical residues make hTRPV1 channels insensitive to capsaicin (Y511A) or decrease the responses to acidic stimuli (E600Q and E649A) (Fig. 5A). To determine the specificity of the stimulation produced by CTDS, we explored which of these residues participate in their detection. Because both calcium and magnesium salts stimulate rat TRPV1 channels by direct activation through E600 and by sensitization through E648 (Ahern et al., 2005), we measured how these mutations would affect CTDS responses.

Figure 5 shows typical responses of CTDS in cells transiently expressing the mutant and the WT TRPV1 channels. For nonmutated hTRPV1, all four CTDS (green) evoked rapid increases in fluorescence that either reached a plateau or declined slowly $\left(\mathrm{MgSO}_{4}\right)$. For E649A channels (red), the responses to zinc, copper, and magnesium sulfates were markedly decreased compared with the WT controls. When stimulated with $\mathrm{FeSO}_{4}, \mathrm{E} 649 \mathrm{~A}$ showed a maximal fluorescence intensity response very similar to 


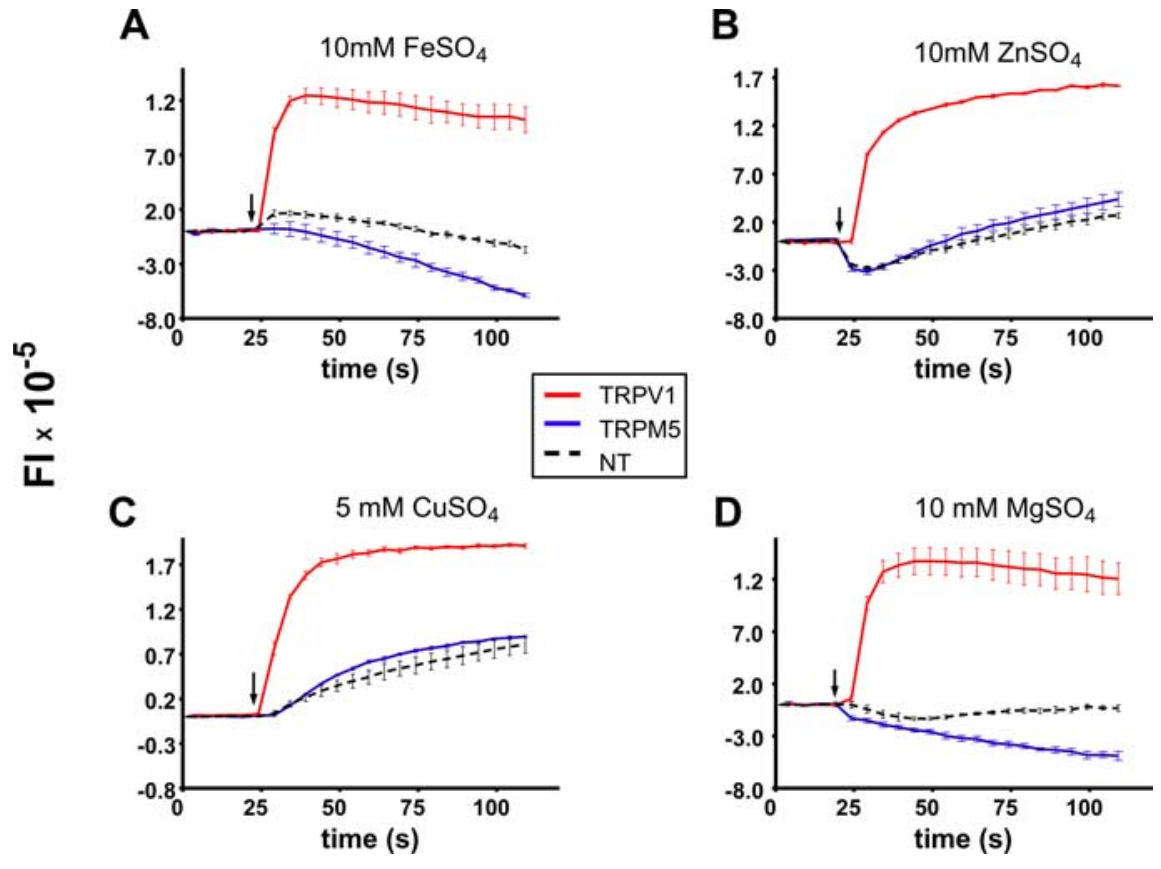

Figure 4. CTDS do not directly stimulate TRPM5 channels. Voltage changes of HEK293 cells loaded with Red dye after stimulation with $10 \mathrm{~mm} \mathrm{FeSO}_{4}(\boldsymbol{A}), 10 \mathrm{~mm} \mathrm{ZnSO}_{4}(\boldsymbol{B}), 5 \mathrm{~mm} \mathrm{CuSO}_{4}(\boldsymbol{C})$, and $10 \mathrm{~mm} \mathrm{MgSO}_{4}(\boldsymbol{A})$, expressed as fluorescence intensity (FI) versus time, are shown. Nontransfected cells (dotted line) and transiently transfected cells with hTRPM5 (blue) and hTRPV1 (red) are shown. All these salts activate TRPV1-expressing cells but have little or no effect on TRPM5-expressing or nontransfected cells.

the WT channel but, contrary to it, rapidly desensitized (Fig. $5 A$ ). Compared with the WT, E600Q channels (gray) did not evoke responses to $\mathrm{ZnSO}_{4}, \mathrm{CuSO}_{4}$, and $\mathrm{MgSO}_{4}$. The capsaicininsensitive mutant Y511A (blue), however, retained its full ability to respond to these divalent salts.

\section{Discussion}

Because of their use as food supplements and as important nutrients in the diet, the sensory characteristics of CTDS are of general interest. In contrast to tastants such as sucrose that evoke a single taste quality, CTDS exhibit a multiplicity of taste descriptors, suggesting that several pathways are involved in elaborating their sensation. Moreover, the sensory profiles of two of these compounds change with concentration: they comprise hedonically positive phases at low concentrations and hedonically negative phases at high concentrations. Here, we have shown that $\mathrm{FeSO}_{4}$ and $\mathrm{ZnSO}_{4}$ exhibit biphasic responses with a hedonically positive phase mediated by a pathway containing T1R3 and TRPM5 at low concentrations and a hedonically negative TRPM5independent, and for $\mathrm{FeSO}_{4}$ a TRPV1-dependent phase at high concentrations. The primarily bitter-tasting compounds $\mathrm{MgSO}_{4}$ and $\mathrm{CuSO}_{4}$ exhibit monotonic hedonically negative responses mediated by TRPM5 and TRPV1 pathways. The summarized findings in Figure 6 indicate that tastants with complex descriptors activate several pathways and that particular sensation is critically dependent on the concentration.

\section{The taste of CTDS has multiple components and depends on concentration}

To identify some of the molecular pathways of CTDS taste transduction, we selected four divalent salts to be evaluated by WT and KO mice defective in their sensory perceptions, either lacking gustatory (TRPM5 and T1R3) and/or somatosensory (TRPV1) elements.

Our data show that in both the TBP and BA tests, $\mathrm{FeSO}_{4}$ and
$\mathrm{ZnSO}_{4}$ present biphasic response profiles (Figs. 1, 2). Their PR- or LR-concentration profiles comprise a slowly increasing hedonically positive phase and a more rapidly increasing hedonically negative phase. The hedonically positive component arises mostly from the interaction of $\mathrm{FeSO}_{4}$ and $\mathrm{ZnSO}_{4}$ with a T1R3-TRPM5-mediated pathway. In T1R3 or TRPM5 KO animals, the loss of these pathways completely suppresses the hedonically positive phase (Figs. $1 A, B, 2 A, B, 3$ ), except in T1R3 $\mathrm{KO}$ mice in which $\mathrm{ZnSO}_{4}$ conveys a small hedonically positive response.

TRPM5 also contributes to the hedonically negative response for $\mathrm{CuSO}_{4}$ and $\mathrm{MgSO}_{4}$. Consistent with our findings, previous work reported that the glossopharyngeal nerve responses to $\mathrm{MgSO}_{4}$ are reduced in TRPM5 KO mice compared with WT animals (Damak et al., 2006).

We also found that TRPV1 contributes to the aversive response to $\mathrm{FeSO}_{4}$ and $\mathrm{CuSO}_{4}$ because knocking it out increases the PR (LR) or preferences for these two salts. The TRPV1 contribution to the behavioral data is likely to come from its expression in somatosensory nociceptors and/or from its expression in TRPM5 cells that contain TRPV1t and that evoke an aversive response (Lyall et al., 2004, 2005; Hacker and Medler, 2008).

Bitter, salty, sour, and umami compounds are avoided by mice at high concentrations, and this aversion is not always accounted for by the receptors and pathways known to be involved in the transduction of those tastes. For example, one strain of TRPM5 KO mice responds to bitter and umami compounds at high concentrations (Damak et al., 2006), and P2X2/P2X3 double-KO mice avoid citric acid despite a total lack of response to this compound from their chorda tympani and glossopharyngeal nerves (Finger et al., 2005). These residual responses could be partly accounted for by TRPV1, as is the case for metals.

Together, our data show that there is a TRPM5- and TRPV1independent pathway of unknown identity for the signal transduction of the four salts tested. The $\mathrm{pH}$ of the solutions (Fig. 2; supplemental Table S1, available at www.jneurosci.org as supplemental material) may play a role by modifying the response of receptors and channels to the tastants or by activating acidsensing ion channels and/or TRPV1 in nociceptors (Waldmann et al., 1997; Tominaga et al., 1998) and PKDL1 receptors in taste receptor cells (TRCs) (Huang et al., 2006). Sour taste could contribute to the response at the highest concentrations of $\mathrm{FeSO}_{4}$ because mice avoid solutions of $\mathrm{HCl}$ with $\mathrm{pH} \leq 3$ (Wong et al., 1996).

Postingestive cues likely contribute to the aversion that mice showed to all the salts tested. Salts of iron, zinc, and copper have strong emetic properties, and the ingestion of large amounts of these compounds by the mice is likely to cause gastrointestinal malaise (Wang and Borison, 1951; Reissman et al., 1955; Makale and King, 1992; Barceloux, 1999). A contribution of the postingestive effect is observed when we compare the results of the BA test with those of the TBP test. In the BA test, aversion is observed at higher concentrations.

The complex effects of the CTDS observed in mice are a func- 
tion of concentration and $\mathrm{pH}$ values (Figs. 1, 2; supplemental Table S1, available at www.jneurosci.org as supplemental material). However, these components are not usually investigated in human psychophysics studies in which single concentrations are often used. Because CTDS solutions are frequently evaluated at high concentrations (Keast et al., 2004; Yang and Lawless, 2005; Lim and Lawless, $2005 \mathrm{~b}$ ), where the $\mathrm{pH}$ is quite acidic (supplemental Table S1, available at www. jneurosci.org as supplemental material), this component may explain some of the descriptors (sour, astringent) associated with the salts. CTDS evoke similar biphasic taste responses as described for $\mathrm{NaCl}$ in which the hedonically positive phase is taste related and the hedonically negative one arises from the activation of nociceptive sensory neurons (Kawamura et al., 1968).

Taste cells and receptors encoding the taste of CTDS at the periphery

Bitter, sweet, and umami tastes are transduced at the periphery by discrete subpopulations of taste cells expressing specific receptors (Zhang et al., 2003). Based on this information, our results, together with those reported in the recent publication of Tordoff et al. (2008), suggest that many subgroups of both TRCs and receptors are implicated in the taste transduction of CTDS (Fig. 6). Among these groups are as follows:

(1) A subpopulation of taste cells expressing T1R3 that respond to magnesium and calcium and project to the taste areas in the brain that underlie aversion (Tordoff et al., 2008). Receptors for sweet and umami are heterodimers of T1R3-T1R2 and T1R3T1R1, respectively, and T1R3 alone responds very weakly to sweeteners (Zhao et al., 2003). Furthermore, some taste cells express T1R3 but not T1R1 or T1R2 (Nelson et al., 2001). Therefore, the cells responsive to $\mathrm{Mg}^{2+}$ and $\mathrm{Ca}^{2+}$ may express another receptor that dimerizes with T1R3 to form an $\mathrm{Mg}^{2+}$ and $\mathrm{Ca}^{2+}$ responsive receptor. The partner of T1R3 in such proposed heterodimer is unlikely to be T1R2 or T1R1 because activation of T1R3 heterodimers containing these receptors leads to preference. Tordoff et al. (2008) suggested that the T1R3 partner might be the calcium sensing receptor, CaSR.

(2) A subpopulation of taste cells that express T1R3 respond to $\mathrm{FeSO}_{4}$ and $\mathrm{ZnSO}_{4}$ and are presumably connected with the areas in the brain underlying preference. The partner of T1R3 in those cells could be either both T1R2 and T1R1 or another G-protein-coupled receptor.

(3) A subpopulation of taste cells that does not express T1R3 but expresses TRPM5 and is responsible for the preference for $\mathrm{Mg}^{2+}$ and $\mathrm{Ca}^{2+}$ and possibly of part of the preference for $\mathrm{Fe}^{2+}$ and $\mathrm{Zn}^{2+}$. This is based on the observations that T1R3 KO mice prefer $\mathrm{Mg}^{2+}$ and $\mathrm{Ca}^{2+}$ (Tordoff et al., 2008), the preference being masked in WT animals by the aversive contribution of T1R3expressing cells, and that $\mathrm{T} 1 \mathrm{R} 3 \mathrm{KO}$ mice tend to be less aversive to $\mathrm{Fe}^{2+}$ and $\mathrm{Zn}^{2+}$ than TRPM5 $\mathrm{KO}$ animals. Based on the latter observation, we assume that these cells express TRPM5 also be-

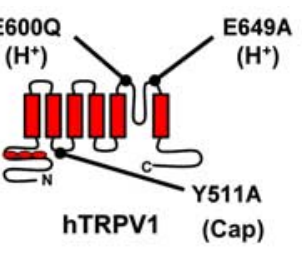

$\mathrm{FeSO}_{4}$
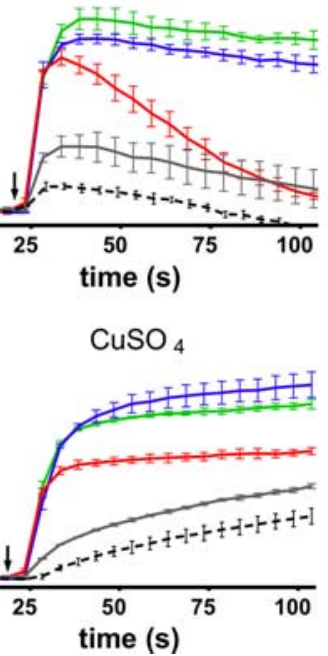

$\mathrm{CuSO}_{4}$

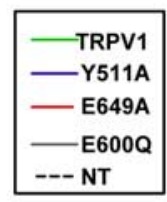

C

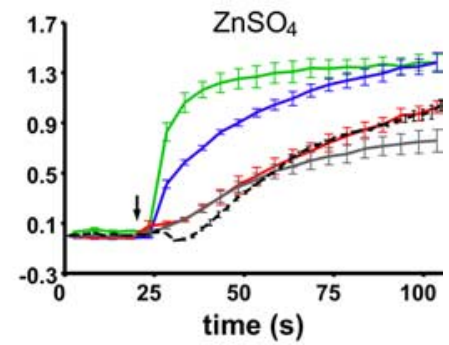

E

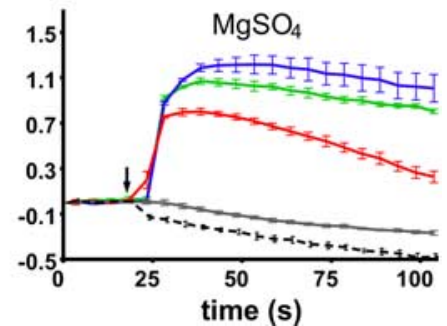

Figure 5. CTDS target the proton-binding sites in hTRPV1. HEK293 cells expressing the TRPV1 point mutants Y511A (blue), (b6) E600Q (black), the WT TRPV1 (green), and nontransfected cells (NT; dashed line) were stimulated with CTDS, and to these stimuli. Typical responses to the different CTDS are shown: $\boldsymbol{A}, 10 \mathrm{~mm} \mathrm{FeSO}_{4} ; \boldsymbol{B}, 10 \mathrm{~mm} \mathrm{ZnSO}_{4} ; \boldsymbol{C}, 5 \mathrm{~mm} \mathrm{CuSO} ; \mathbf{D}, 10 \mathrm{~mm}$ $\mathrm{MgSO}_{4}$. Data are means $\pm \mathrm{SEM}(n=3)$.

cause TRPM5 KO mice are indifferent to concentrations of $\mathrm{Mg}^{2+}$ preferred by T1R3 KO mice.

(4) A subpopulation of cells that do not express TRPM5 but are responsive to $\mathrm{FeSO}_{4}, \mathrm{ZnSO}_{4}$ and $\mathrm{CuSO}_{4}$ and lead to aversion. In addition, TRPV1 in nerve terminals and possibly TRPV1t in taste cells, but also tactile cues, may play a role in the aversive taste of $\mathrm{FeSO}_{4}$ and $\mathrm{CuSO}_{4}$.

\section{Heterologously expressed TRPM5 and TRPV1 channel} responses provide information on the molecular mechanisms of CTDS sensory properties

Several lines of evidence show that divalent salts of $\mathrm{Fe}^{2+}, \mathrm{Cu}^{2+}$, and $\mathrm{Zn}^{2+}$ permeate cells through active and passive transmembrane transport pathways (Gutknecht, 1981; Powell et al., 1999). They may also pass through tight junctions having a selective permeability to divalent cations (Tang and Goodenough, 2003; Ikari et al., 2004). In the taste bud, tight junctions act as a protective barrier of the TRCs and play an important role in salt taste (Simon, 1992; DeSimone et al., 1993).

We investigated whether these CTDS would stimulate heterologously expressed TRPM5, which in TRCs are expressed on the basolateral surface. We found that CTDS applied to the extracellular surface did not directly activate TRPM5 channels (Fig. 4), suggesting that this mechanism is unlikely to occur in vivo. These results are consistent with the behavioral data showing a role for T1R3 in the preference for CTDS. Together, these data suggest that TRPM5 is activated by calcium release from stores after activation of PLC $\beta 2$ by the action of $\mathrm{Fe}^{2+}$ or $\mathrm{Zn}^{2+}$ ions on T1R3.

In addition, consistent with the role of TRPV1 as a sensor of 


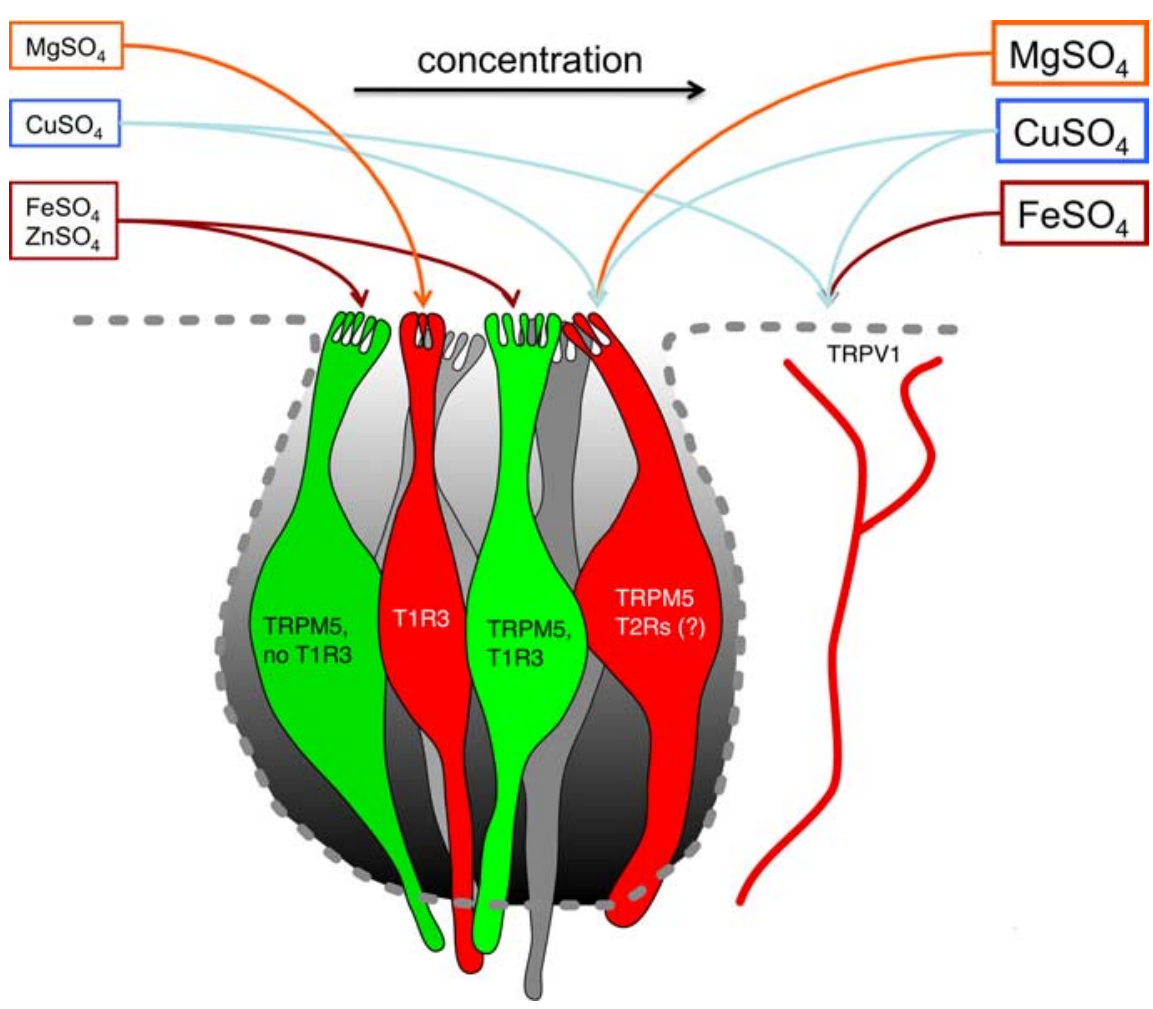

Figure 6. Complexity of coding at the periphery integrating gustatory and trigeminal stimuli to explain CTDS hedonic responses. Gustatory cells in the taste bud (gray) segregate in cells imparting preference behavior (green) and avoidance (red). The arrow indicates increasing concentration. Based on the results of this study, hedonically positive cells occur at least in two subpopulations both expressing TRPM5 but only one expressing TRPM5 together with T1R3. Hedonically negative avoidance behavior is triggered in part through activation of another subset of TRPM5-expressing cells; likely, these cells also express T2R bitter taste receptors. Another subset of hedonically negative cells contains T1R3, as suggested by Tordoffet al. (2008). Free nerve endings in the taste epithelium of TRPV1-expressing sensory neurons convey hedonically aversive sensations. To explain the switch from preference to avoidance behavior at increasing concentrations, the ratio of cells activated changes from a majority of preference cells to a majority of avoidance cells. CTDS listed at the left in small letters indicate low concentrations, and those to the right indicate high concentrations. Foir $\mathrm{ZnSO}_{4}$, the aversion is independent of TRPM5 and TRPV1 (pathway not indicated).
Ahern GP, Wang X, Miyares RL (2006) Polyamines are potent ligands for the capsaicin receptor TRPV1. J Biol Chem 281:8991-8995.

Bandell M, Macpherson LJ, Patapoutian A (2007) From chills to chilis: mechanisms for thermosensation and chemesthesis via thermoTRPs. Curr Opin Neurobiol 17:490-497.

Barceloux DG (1999) Zinc. J Toxicol Clin Toxicol 37:279-292.

Caterina MJ, Schumacher MA, Tominaga M, Rosen TA, Levine JD, Julius D (1997) The capsaicin receptor: a heat-activated ion channel in the pain pathway. Nature 389:816-824.

Caterina MJ, Leffler A, Malmberg AB, Martin WJ, Trafton J, Petersen-Zeitz KR, Koltzenburg M, Basbaum AI, Julius D (2000) Impaired nociception and pain sensation in mice lacking the capsaicin receptor. Science 288:306-313.

Civille GV, Lyon BG (1996) Aroma and flavor lexicon for sensory evaluation. Washington DC: ASTM.

Damak S, Rong M, Yasumatsu K, Kokrashvili Z, Varadarajan V, Zou S, Jiang P, Ninomiya Y, Margolskee RF (2003) Detection of sweet and umami taste in the absence of taste receptor T1r3. Science 301:850-853.

Damak S, Rong M, Yasumatsu K, Kokrashvili Z, Perez CA, Shigemura N, Yoshida R, Mosinger B Jr, Glendinning JI, Ninomiya Y, Margolskee RF (2006) Trpm5 null mice respond to bitter, sweet, and umami compounds. Chem Senses 31:253-264.

DeSimone JA, Ye Q, Heck GL (1993) Ion pathways in the taste bud and their significance for transduction. Ciba Found Symp 179:218-229.

Finger TE, Danilova V, Barrows J, Bartel DL, Vigers AJ, Stone L, Hellekant G, Kinnamon SC (2005) ATP signaling is crucial for communication from taste buds to gustatory nerves. Science 310:1495-1499.

Glendinning JI, Gresack J, Spector AC (2002) A high-throughput screening procedure for identifying mice with aberrant taste and oromotor function. Chem Senses 27:461-474.

Gutknecht J (1981) Inorganic mercury $\left(\mathrm{Hg}^{2+}\right)$ aversive compounds, we found that CTDS are agonists for heterologously expressed hTRPV1. Their effects occur via glutamates E600 and E649 as observed previously in the direct gating by $\mathrm{Mg}^{2+}$ and $\mathrm{Ca}^{2+}$ (Ahern et al., 2005). Interestingly, we found no TRPV1 contribution in the behavioral response to $\mathrm{MgSO}_{4}$ despite its established role in inducing pain via TRPV1 receptors (Ahern et al., 2005). This is likely because $\mathrm{MgSO}_{4}$, unlike the other divalent salts, has a limited diffusion into the epithelium (Powell et al., 1999; Tang and Goodenough, 2003). Our results, however, confirm the role of hTRPV1 as a sensor of $\mathrm{FeSO}_{4}$ and $\mathrm{CuSO}_{4}$, although the agonistic activity of $\mathrm{MgSO}_{4}$ and $\mathrm{ZnSO}_{4}$ on heterologous hTRPV1 in vitro does not appear to be physiologically relevant for perception.

\section{Summary}

This study provides a molecular rationalization of the sensory properties of CTDS. It shows that TRPM5-, T1R3-, and TRPV1containing pathways are the main peripheral molecular targets of these compounds (Fig. 6). Other T1R3-, TRPM5-, and TRPV1independent pathways also exist and contribute to preference for $\mathrm{FeSO}_{4}$ and $\mathrm{ZnSO}_{4}$ and aversion for the four CTDS.

\section{References}

Ahern GP, Brooks IM, Miyares RL, Wang XB (2005) Extracellular cations sensitize and gate capsaicin receptor TRPV1 modulating pain signaling. J Neurosci 25:5109-5116. transport through lipid bilayer membranes. J Membr Biol 61:61-66.

Hacker K, Medler KF (2008) Mitochondrial calcium buffering contributes to the maintenance of Basal calcium levels in mouse taste cells. J Neurophysiol 100:2177-2191.

Huang AL, Chen X, Hoon MA, Chandrashekar J, Guo W, Trankner D, Ryba NJ, Zuker CS (2006) The cells and logic for mammalian sour taste detection. Nature 442:934-938.

Ikari A, Hirai N, Shiroma M, Harada H, Sakai H, Hayashi H, Suzuki Y, Degawa M, Takagi K (2004) Association of paracellin-1 with ZO-1 augments the reabsorption of divalent cations in renal epithelial cells. J Biol

Jordt SE, Julius D (2002) Molecular basis for species-specific sensitivity to "hot" chili peppers. Cell 108:421-430.

Jordt SE, Tominaga M, Julius D (2000) Acid potentiation of the capsaicin receptor determined by a key extracellular site. Proc Natl Acad Sci U S A 97:8134-8139.

Kaske S, Krasteva G, Konig P, Kummer W, Hofmann T, Gudermann T, Chubanov V (2007) TRPM5, a taste-signaling transient receptor potential ion-channel, is a ubiquitous signaling component in chemosensory cells. BMC Neurosci 8:49.

Kawamura Y, Okamoto J, Funakoshi M (1968) A role of oral afferents in aversion to taste solutions. Physiol Behav 3:537-542.

Keast RS, Bournazel MM, Breslin PA (2003) A psychophysical investigation of binary bitter-compound interactions. Chem Senses 28:301-313.

Keast RS, Canty TM, Breslin PA (2004) Oral zinc sulfate solutions inhibit sweet taste perception. Chem Senses 29:513-521.

Lawless HT, Schlake S, Smythe J, Lim J, Yang H, Chapman K, Bolton B (2004) Metallic taste and retronasal smell. Chem Senses 29:25-33. Chem 279:54826-54832. 
Lawless HT, Stevens DA, Chapman KW, Kurtz A (2005) Metallic taste from electrical and chemical stimulation. Chem Senses 30:185-194.

Lim J, Lawless HT (2005a) Oral sensations from iron and copper sulfate. Physiol Behav 85:308-313.

Lim J, Lawless HT (2005b) Qualitative differences of divalent salts: multidimensional scaling and cluster analysis. Chem Senses 30:719-726.

Lyall V, Heck GL, Vinnikova AK, Ghosh S, Phan TH, Alam RI, Russell OF, Malik SA, Bigbee JW, DeSimone JA (2004) The mammalian amilorideinsensitive non-specific salt taste receptor is a vanilloid receptor- 1 variant. J Physiol 558:147-149.

Lyall V, Heck GL, Vinnikova AK, Ghosh S, Phan TH, DeSimone JA (2005) A novel vanilloid receptor-1 (VR-1) variant mammalian salt taste receptor. Chem Senses 30 [Suppl 1]:i42-i43.

Makale MT, King GL (1992) Surgical and pharmacological dissociation of cardiovascular and emetic responses to intragastric CuSO4. Am J Physiol 263:R284-R291.

Martell AE, Hancock RD (1996) Metal complexes in aqueous solutions. New York: Springer.

Nelson G, Hoon MA, Chandrashekar J, Zhang Y, Ryba NJ, Zuker CS (2001) Mammalian sweet taste receptors. Cell 106:381-390.

O’Dell BL, Sunde RA (1997) Handbook of nutritionally essential mineral elements, pp 493-556. New York: Marcel Dekker.

Pfaffmann C (1980) Wundt's schema of sensory affect in the light of research on gustatory preferences. Psychol Res 42:165-174.

Powell JJ, Jugdaohsingh R, Thompson RP (1999) The regulation of mineral absorption in the gastrointestinal tract. Proc Nutr Soc 58:147-153.

Prawitt D, Monteilh-Zoller MK, Brixel L, Spangenberg C, Zabel B, Fleig A, Penner R (2003) TRPM5 is a transient Ca2+-activated cation channel responding to rapid changes in $[\mathrm{Ca} 2+]$ i. Proc Natl Acad Sci U S A 100:15166-15171.

Reissman KR, Coleman TJ, Budai BS, Moriarty LR (1955) Acute intestinal iron intoxication. I. Iron absorption, serum iron and autopsy findings. Blood 10:35-45.

Riera CE, Vogel H, Simon SA, le Coutre J (2007) Artificial sweeteners and salts producing a metallic taste sensation activate TRPV1 receptors. Am J Physiol Regul Integr Comp Physiol 293:R626-R634.
Riera CE, Vogel H, Simon SA, Damak S, le Coutre J (2008) The capsaicin receptor participates in artificial sweetener aversion. Biochem Biophys Res Commun 376:653-657.

Schiffman SS, Erickson RP (1971) A psychophysical model for gustatory quality. Physiol Behav 7:617-633.

Simon SA (1992) Influence of tight junctions on the interaction of salts with lingual epithelia: responses of chorda tympani and lingual nerves. Mol Cell Biochem 114:43-48.

Simon SA, De Araujo IE, Gutierrez R, Nicolelis MA (2006) The neural mechanisms of gustation: a distributed processing code. Nat Rev Neurosci 7:890-901.

Tang VW, Goodenough DA (2003) Paracellular ion channel at the tight junction. Biophys J 84:1660-1673.

Tominaga M, Caterina MJ, Malmberg AB, Rosen TA, Gilbert H, Skinner K, Raumann BE, Basbaum AI, Julius D (1998) The cloned capsaicin receptor integrates multiple pain-producing stimuli. Neuron 21:531-543.

Tordoff MG, Shao H, Alarcon LK, Margolskee RF, Mosinger B, Bachmanov AA, Reed DR, McCaughey SA (2008) Involvement of T1R3 in calciummagnesium taste. Physiol Genomics 34:338-348.

Waldmann R, Bassilana F, de WJ, Champigny G, Heurteaux C, Lazdunski M (1997) Molecular cloning of a non-inactivating proton-gated $\mathrm{Na}+$ channel specific for sensory neurons. J Biol Chem 272:20975-20978.

Wang SC, Borison HL (1951) Copper sulphate emesis; a study of afferent pathways from the gastrointestinal tract. Am J Physiol 164:520-526.

Wong GT, Gannon KS, Margolskee RF (1996) Transduction of bitter and sweet taste by gustducin. Nature 381:796-800.

Yang HH, Lawless HT (2005) Descriptive analysis of divalent salts. J Sens Stud 20:97-113.

Zhang Y, Hoon MA, Chandrashekar J, Mueller KL, Cook B, Wu D, Zuker CS, Ryba NJ (2003) Coding of sweet, bitter, and umami tastes: different receptor cells sharing similar signaling pathways. Cell 112:293-301.

Zhao GQ, Zhang Y, Hoon MA, Chandrashekar J, Erlenbach I, Ryba NJ, Zuker CS (2003) The receptors for mammalian sweet and umami taste. Cell 115:255-266. 